\title{
Ubiquinone in rats deficient in vitamin $A$
}

\author{
By T. MOORE AND I. M. SHARMAN \\ Dunn Nutritional Laboratory, University of Cambridge and Medical Research Council
}

$$
\text { (Received } 23 \text { February 1960-Revised } 27 \text { fune 1960) }
$$

An absorption band at $275 \mathrm{~m} \mu$ was first observed in the livers of rats, restricted in their vitamin A intake, by Moore \& Rajagopal (I940). The aim of their investigation was to study the distribution of vitamin $\mathrm{E}$ throughout the body by measurement of its absorption at $294 \mathrm{~m} \mu$ (Martin, Moore, Schmidt \& Bowden, 1934). For this purpose the intake of vitamin $A$ had to be restricted to no more than an adequate level, so as to prevent masking of the weak absorption of vitamin $\mathrm{E}$ by the intense absorption of vitamin $\mathrm{A}$ at $328 \mathrm{~m} \mu$ (Morton \& Heilbron, 1928). This restriction permitted the measurement of vitamin $\mathrm{E}$ in depot fat, but in liver the substance absorbing at $275 \mathrm{~m} \mu$ prevented satisfactory measurements. The unknown substance appeared to be stable during the digestion of the tissues with dilute $\mathrm{KOH}$, but it disappeared during saponification of the extracted fat with concentrated alcoholic $\mathrm{KOH}$.

Absorption at $275 \mathrm{~m} \mu$ in liver extracts from rats completely deprived of vitamin A was later reported by Lowe, Morton \& Harrison (1953). Subsidiary maxima were observed at 233,283 and $332 \mathrm{~m} \mu$, but their intensity in relation to the main maximum at $275 \mathrm{~m} \mu$ differed in different fractions. It was suggested that the absorption was due to previously unknown metabolites that resulted from 'a lifting of restraint on the dehydrogenation of cholesterol or steroid hormones' during deficiency of vitamin A. Ward \& Moore (1955) confirmed the presence of a band near $275 \mathrm{~m} \mu$ in liver extracts from rats deficient in vitamin A. In agreement with what was found by Moore \& Rajagopal ( 1940 ), the absorption survived during alkaline digestion of the tissues, but disappeared after treatment of the extracted fat with hot alcoholic $\mathrm{KOH}$. When extracts were submitted to paper chromatography, two fractions were separated, one with a single band at $275 \mathrm{~m} \mu$ and the other having a main band at $275 \mathrm{~m} \mu$ and also an inflexion at $33 \circ \mathrm{m} \mu$. Bands at $272-275 \mathrm{~m} \mu$ were also found in liver extracts from rats cured of avitaminosis $A$, from normal sexually immature rats and from a normal pig and guinea-pig. Ward \& Moore (1955) suggested that since a substance with a single band at $275 \mathrm{~m} \mu$ was present in the livers of normal animals, caution was necessary before the acceptance of spectra, with their main bands in this position, as indications of avitaminosis A.

Heaton, Lowe \& Morton (1955, 1957) separated fractions containing substance A, characterized by a sharp band at $272 \mathrm{~m} \mu$ and substance $\mathrm{C}$, having a main band at $275 \mathrm{~m} \mu$ and a lesser band at $330 \mathrm{~m} \mu$, from the livers and other organs of vitamin Adeficient, control and stock-colony rats. In the livers of deficient animals the concentration of substance A was high, and there was also a marked concentration of 
substance C. Cunningham, Lowe, Mervyn, Morton \& Vernon (r955) detected both substances $A$ and $C$ in normal livers and kidneys from various species.

Extensive research by the Liverpool school, reviewed by Morton (1958), eventually established that substance $A$ is not a sterol derivative, but a derivative of I-methyl5,6-dimethoxy-p-benzoquinone. Because of its wide distribution in the tissues he proposed to name it 'ubiquinone'. Many similar compounds, differing in the lengths of their long polyene side-chains, are now known to exist (Lester, Hatefi, Widmer \& Crane, 1959). Alternative names for ubiquinone have included coenzyme $Q$ or Q 275 (Lester, Crane \& Hatefi, 1958) and mitoquinone (Hatefi, Lester \& Ramasarma, 1958). Substance $\mathrm{C}$ has been shown by Laidman, Morton, Paterson \& Pennock (I959) to be a cyclized derivative of ubiquinone, and has been named 'ubichromenol'.

The present paper, however, is concerned neither with the chemistry of ubiquinone and its congeners nor with their role in enzyme systems. Attention will be concentrated on the magnitude of the reported increase of these substances in the tissues during avitaminosis $A$ and on the specificity of any such increases as direct effects of the avitaminosis.

Even in the recent communications of Morton \& Phillips (1959a, b), which give further evidence of increases of ubiquinone and ubichromenol in the livers of rats deficient in vitamin $A$, no emphasis has been placed on the need to estimate these substances by carefully standardized routine methods. Large, but varying amounts of tissue appear to have been examined, by processes that may well have varied in such details as the time found necessary for digesting the tissues and the volumes of solvents used for chromatography. Since ubiquinone is unstable, attention to such details is necessary if losses, at varying rates in different experiments, are not to occur. Moreover it would seem important, in studies of the effect of avitaminosis A on concentrations of ubiquinone and ubichromenol, to include observations on control rats adequately dosed with vitamin $A$.

We decided, therefore, to make spectroscopic examinations of extracts, prepared by a simple, uniform method, from the livers and hearts of numerous individual rats deficient in vitamin $\mathrm{A}$ and of others adequately supplied. Although chromatographic methods may be required for accurate estimations of ubiquinone and ubichromenol, and particularly for their separation, the risks of losses during adsorption and elution have not yet been fully investigated. At the present stage of progress, therefore, it seemed reasonable to hope that useful guidance as to major changes in the concentrations of ubiquinone and ubichromenol might be obtained by the examination of crude extracts, prepared without chromatography. A preliminary account of part of our work has already been given (Moore \& Sharman, 1959).

\section{EXPERIMENTAL}

Estimation of gross ubiquinone contents. The principle of our method was to digest the tissue in $\mathrm{KOH}$, and then extract the digest with diethyl ether. The extract was evaporated, and the residue made up in spectroscopically pure cyclohexane for examination in a Unicam SP 500 spectrophotometer. Gross ubiquinone contents, or in other 
words the maximum amounts of this substance consistent with the intensity of absorption at $272 \mathrm{~m} \mu$, were calculated per $\mathrm{g}$ of the wet tissue on the basis of the pure substance having $E_{1 \mathrm{~cm}}^{1 \%} 272 \mathrm{~m} \mu=167$ (Fahmy, Hemming, Morton, Paterson \& Pennock, I958).

When losses during the digestion of the tissues were avoided, this method gave values for the ubiquinone contents of the final extracts that must often have considerably exceeded the true values. Unsuitable methods of digesting the tissues, on the other hand, were found to cause unduly low results. Preliminary experiments were made on pig heart, which is a convenient source of ubiquinone (Fahmy et al. 1958) and contains only traces of vitamin A. When the tissues were first chopped up with $5 \%(\mathrm{w} / \mathrm{v})$ aqueous $\mathrm{KOH}$, and then placed in a small conical flask in a hot-water oven, complete digestion required about $3 \mathrm{~h}$. In ten estimations values of $7^{-1} 70 \mu \mathrm{g} / \mathrm{g}$, mean 73, of gross ubiquinone were found. This procedure, therefore, often led to almost complete loss of the highly unstable ubiquinone. Higher and more consistent values were obtained when the concentration of the $\mathrm{KOH}$ was increased, and the time of digestion reduced. Thus in thirteen estimations in which $60 \% \mathrm{KOH}$ was used values of $159-263 \mu \mathrm{g} / \mathrm{g}$, mean 209 , were found.

On the assumption that the loss of ubiquinone was associated with the absorption of atmospheric oxygen a procedure was devised by which the exposure of the digesting tissues to air was minimized. As a further step pyrogallol was used to absorb any oxygen unavoidably admitted (Tosic \& Moore, 1945). Alcoholic KOH replaced aqueous so that the tissues might be digested and the liberated fat saponified in one operation. The early finding of Moore \& Rajagopal (1940) that hot alcoholic potash caused the disappearance of absorption at $275 \mathrm{~m} \mu$ from liver fat was presumably due to the absence of any substances, such as pyrogallol or the constituents of liver tissues, that can protect ubiquinone.

Ethanol $(2 \mathrm{ml})$ and $60 \%$ aqueous $\mathrm{KOH}(0.5 \mathrm{ml})$ were heated in a boiling tube on a water-bath. When the air in the tube had been partially replaced by alcohol vapour, pyrogallol was added $(0.5 \mathrm{ml}$ of a $5 \%(\mathrm{w} / \mathrm{v})$ alcoholic solution), and then the finely chopped tissues ( $\mathrm{r} \circ \mathrm{g}$ or less). The digestion was allowed to proceed, with occasional gentle shaking, and was usually complete in $3 \mathrm{~min}$. Water was then added $(5 \mathrm{ml})$ and the digest was extracted twice with Io $\mathrm{ml}$ portions of diethyl ether. The combined extracts were well washed with distilled water and evaporated on a water-bath under reduced pressure. The residue was dissolved in cyclohexane for measurement of the absorption curve, usually between 230 and $360 \mathrm{~m} \mu$. Estimations by this method on six samples of tissues taken from the same heart gave gross values of $188-255 \mu \mathrm{g} / \mathrm{g}$, mean 210 . The absorption spectra shown in Figs. 1 and 2 indicate that, in the absence of vitamin $\mathrm{A}$, extracts prepared by this method displayed the absorption band of ubiquinone.

Correction for vitamin $A$. No correction for vitamin A was necessary in estimations on hearts, or on the livers of rats that had either been deprived of vitamin A or had been given barely adequate doses of it. When larger doses had been given to rats, however, the spectra indicated clearly that substantial amounts of vitamin A were present, with the absorption at $328 \mathrm{~m} \mu$ greatly exceeding that at $272 \mathrm{~m} \mu$. 
In measuring the gross ubiquinone contents of these livers a correction was applied in four stages: (1) The mean was calculated for the absorption at $328 \mathrm{~m} \mu / \mathrm{g}$ liver in extracts from rats deficient in vitamin A. (2) This mean value was deducted from the absorption at $328 \mathrm{~m} \mu$ for each of the rats dosed with vitamin $A$. This method of correction was preferred to corrections between pairs of rats, dosed and undosed, so as to avoid undue effects of individual variations in the undosed group. (3) The corrected absorptions at $328 \mathrm{~m} \mu$ thus determined were multiplied by 0.140 , the factor relating the absorption of vitamin $A$ at $272 \mathrm{~m} \mu$ to the absorption at $328 \mathrm{~m} \mu$ (Cama, Collins \& Morton, I95I). (4) The products so obtained were deducted from the absorptions at $272 \mathrm{~m} \mu$ in the extracts from the rats dosed with vitamin A, and maximum ubiquinone contents were calculated from the difference. An example of the effect of this correction procedure is given in Fig. 3 .

In all the livers vitamin A was also estimated by the antimony-trichloride method. The results agreed reasonably well with the spectrophotometric readings at $328 \mathrm{~m} \mu$ and need not be reported in detail.

Ubichromenol. Throughout the investigation the curves with the sharpest bands at $272 \mathrm{~m} \mu$ gave no indication of the secondary band at $330 \mathrm{~m} \mu$ from which the presence of ubichromenol might have been inferred (Figs. I and 2). Absorption at $328 \mathrm{~m} \mu$ was naturally observed in those livers in which substantial amounts of vitamin A were present. In the circumstances no attempt could have been made to estimate such small amounts of ubichromenol as may possibly have been present without giving up our principle of using methods of estimation that avoid chromatography.

Preparation of rats. In two experiments piebald rats of both sexes were taken soon after weaning and given basal diets deficient in vitamin $A$, either with or without supplements of the vitamin. When signs of avitaminosis A, such as cessation of growth, xerophthalmia or haematuria, had developed in the undosed rats they were killed for ubiquinone estimations. A few of the animals died spontaneously. There was no evidence that the ubiquinone contents of their organs were different from those of the rats that had been killed, and results for rats that died or were killed have been included in the same tables and calculations. At about the same times as the deficient rats were killed or died, dosed rats of the same sex were killed.

In Expt I the basal diet contained casein (vitamin-free) 20, sucrose 60, arachis oil i 5 , dried yeast 10 and minerals 5 parts. Vitamin $\mathrm{E}$ was supplied as $2 \mathrm{mg} \mathrm{DL}-\alpha$-tocopheryl acetate/rat weekly, vitamin $\mathrm{D}$ as 60 i.u. $(\mathrm{r} \cdot 5 \mu \mathrm{g})$ ergocalciferol and vitamin $\mathrm{K}$ as $50 \mu \mathrm{g}$ 2-methyl-I,4-naphthoquinone. The rats dosed with vitamin A received 40 i.u. weekly, as the synthetic acetate.

In Expt 2 the rats received a diet of casein (vitamin-free) 25, sucrose 50, lard 10, dried yeast Io, and minerals 5 parts. Fat-soluble vitamins were supplied as in Expt $x$, except that the dose for the rats given vitamin A was rooo i.u. weekly. Since lard usually contains traces of vitamin A (Ames \& Harris, 1954), this diet was probably less rigorously deficient in the vitamin than when the fat was supplied as arachis oil. 
RESULTS

Expt 1. Growth in the rats not dosed with vitamin A stopped after 4-5 weeks, and all the animals eventually showed clear signs of avitaminosis A. Observations on changes in body-weight, on the lesions developed, and on the maximum ubiquinone contents of the livers and hearts are summarized in Table $\mathbf{I}$. All the rats dosed with

Table I. Expt $\mathrm{I}$. Gross amounts of ubiquinone in the livers and hearts of rats deficient in vitamin $A$ or given barely adequate doses

(No correction for the presence of vitamin A was necessary in this experiment)

\begin{tabular}{|c|c|c|c|c|c|c|c|c|c|}
\hline \multirow{4}{*}{$\begin{array}{l}\text { Rat no. } \\
\text { and sex }\end{array}$} & \multirow{4}{*}{$\begin{array}{l}\text { Days } \\
\text { on } \\
\text { diet }\end{array}$} & & & & \multirow[b]{4}{*}{ Remarks } & \multicolumn{4}{|c|}{ Ubiquinone } \\
\hline & & \multirow{2}{*}{\multicolumn{3}{|c|}{ Body-weight (g) }} & & \multicolumn{2}{|c|}{ Liver } & \multicolumn{2}{|c|}{ Heart } \\
\hline & & & & & & \multirow[b]{2}{*}{$\mu \mathrm{g} / \mathrm{g}$} & \multirow{2}{*}{$\begin{array}{l}\text { Total } \\
(\mu \mathrm{g})\end{array}$} & \multirow[b]{2}{*}{$\mu g / g$} & \multirow{2}{*}{$\begin{array}{l}\text { Total } \\
(\mu \mathrm{g})\end{array}$} \\
\hline & & Initial & Maximal & Final & & & & & \\
\hline \multicolumn{10}{|c|}{ Vitamin A-deficient } \\
\hline 10 & 49 & $\begin{array}{l}78 \\
80\end{array}$ & 230 & 167 & Xerophthalmia & $34{ }^{\circ}$ & 2400 & 500 & 290 \\
\hline 20 & 49 & $\begin{array}{l}89 \\
92\end{array}$ & $\begin{array}{l}250 \\
238\end{array}$ & 200 & & $\begin{array}{l}520 \\
550\end{array}$ & $\begin{array}{l}3900 \\
3300\end{array}$ & $\begin{array}{l}400 \\
730\end{array}$ & \\
\hline $\begin{array}{l}30 \\
40\end{array}$ & $\begin{array}{l}53 \\
58\end{array}$ & $8 \mathrm{r}$ & 233 & $\begin{array}{l}191 \\
208\end{array}$ & $\begin{array}{l}\text { Xerophthalmia } \\
\text { Xerophthalmia }\end{array}$ & 350 & 2100 & 650 & $\begin{array}{l}390 \\
400\end{array}$ \\
\hline $\begin{array}{l}4 \% \\
5 \%\end{array}$ & 51 & 76 & 178 & 168 & $\begin{array}{l}\text { Xerophthalmia } \\
\text { Xerophthalmia }\end{array}$ & 470 & 2600 & 390 & 250 \\
\hline 69 & $5 \mathrm{I}$ & 75 & 176 & 168 & Xerophthalmia & 400 & 2700 & 340 & 220 \\
\hline 7 운 & 62 & 89 & 191 & 186 & Xerophthalmia & $83^{\circ}$ & 6400 & 560 & 340 \\
\hline 80 & 62 & 59 & 157 & 140 & Died; xerophthalmia, & 720 & 3200 & 580 & 260 \\
\hline & an & 80 & 207 & 179 & & 520 & 3300 & 520 & 300 \\
\hline \multicolumn{10}{|c|}{ Adequately supplied } \\
\hline $90^{*}$ & 50 & 79 & 292 & 292 & Normal & 280 & 3900 & $43^{\circ}$ & $33^{\circ}$ \\
\hline 100 & 50 & 85 & 301 & 301 & Normal & $35^{\circ}$ & 5100 & 290 & 260 \\
\hline$x \times \sigma^{*}$ & 55 & 85 & 321 & $32 \mathrm{I}$ & Normal & 270 & 3900 & 540 & 480 \\
\hline 120 & 58 & 84 & 303 & 303 & Normal & 290 & 4800 & 410 & 360 \\
\hline 139 & $5 \mathrm{I}$ & 89 & 217 & 217 & Normal & 320 & 2900 & 590 & 410 \\
\hline 149 & $5^{I}$ & 70 & 186 & 186 & Normal & 420 & 3500 & 620 & $4 \mathrm{ro}$ \\
\hline $15 \%$ & 62 & 60 & 196 & 196 & Normal & $34^{\circ}$ & 2800 & $44^{\circ}$ & 290 \\
\hline 169 & 62 & 54 & 164 & 164 & Normal & 440 & 3200 & 570 & $35^{\circ}$ \\
\hline \multicolumn{2}{|c|}{ Mean } & 76 & 248 & 248 & & $34^{\circ}$ & 3800 & 490 & 360 \\
\hline
\end{tabular}

vitamin A remained in good health, and continued to grow throughout the experiment. Estimations of vitamin A in their livers by the antimony-trichloride method, however, confirmed our expectation that only traces of the vitamin would be stored. Values for gross ubiquinone in the dosed rats are also included in Table $I$. It will be seen that in the deficient rats the livers contained $340-830 \mu \mathrm{g} / \mathrm{g}$, mean 520 , of gross ubiquinone, and the hearts $340-730 \mu \mathrm{g}$, mean 520 . For the dosed rats the values for liver were $270-440 \mu \mathrm{g}$, mean 340 , and for heart $290-620 \mu \mathrm{g}$, mean 490 .

Fig. I gives the mean absorption curves for liver in the groups of deficient and control rats and also includes a curve showing the difference between the means. The absorption curve for pure ubiquinone from pig's heart (Morton, Gloor, Schindler, Wilson, Chopard-dit-Jean, Hemming, Isler, Leat, Pennock, Rüegg, Schwieter \& 


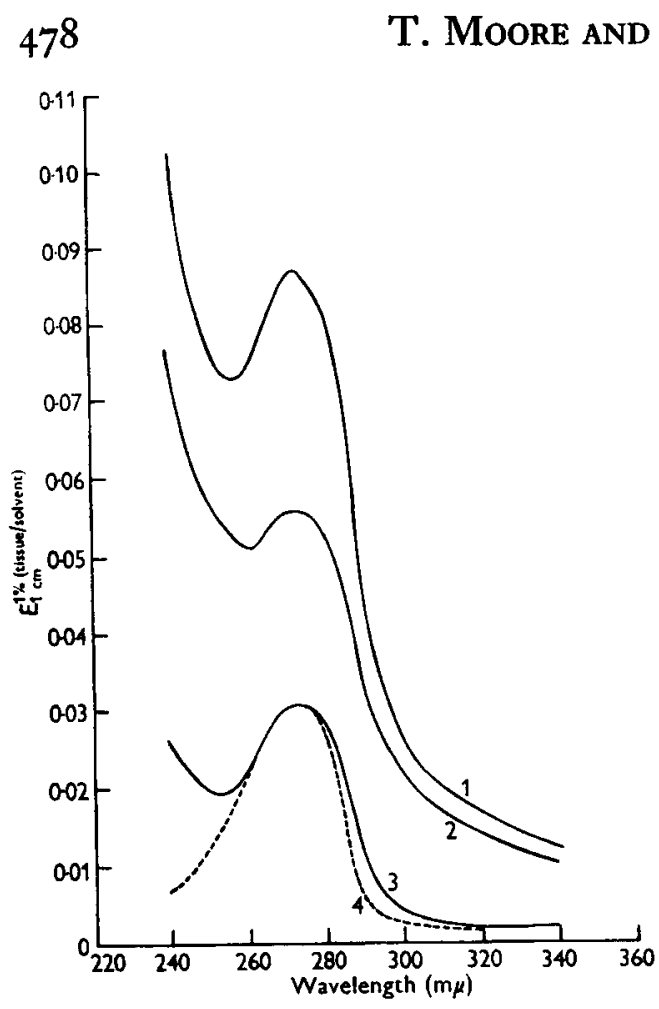

Fig. I

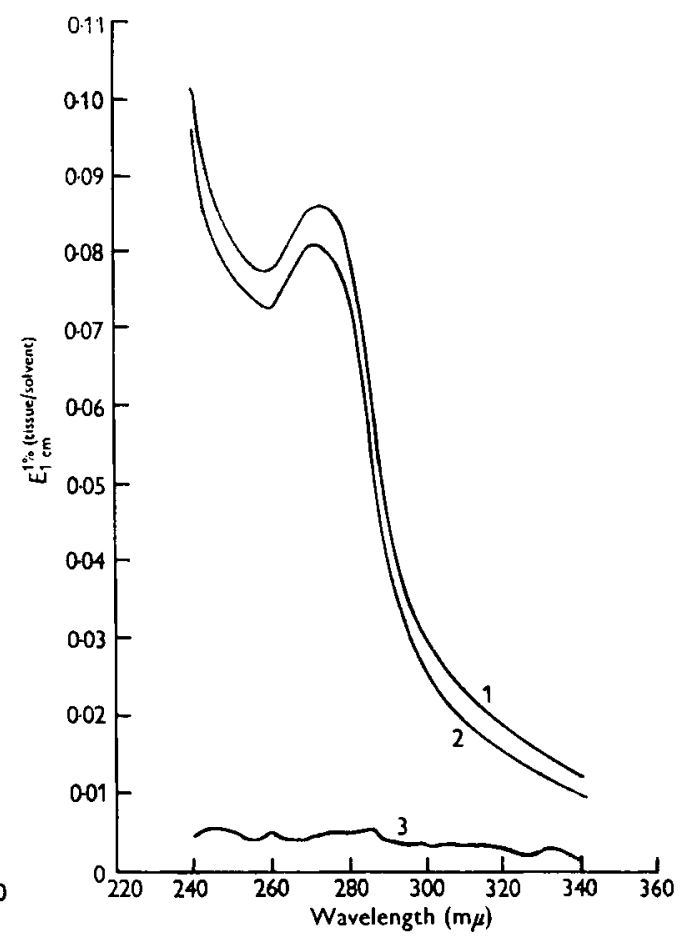

Fig. 2

Fig. I. Expt I. Mean absorption curves for liver extracts from rats. Curve I, vitamin Adeficient rats; curve 2, control rats; curve 3, difference between curves I and 2; curve 4, pure ubiquinone.

Fig. 2. Expt 1. Mean absorption curves for heart extracts from rats. Curve I, vitamin Adeficient rats; curve 2 , control rats; curve 3 , difference between curves $I$ and 2 .

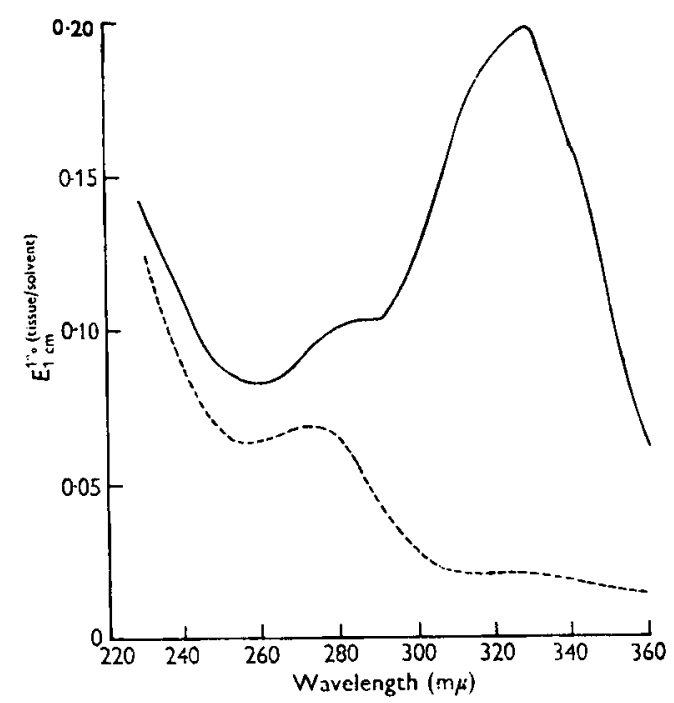

Fig. 3. Expt 2. Correction of absorption spectrum for vitamin $A$ as applied to liver extract from rat, no. $28 \delta$, dosed with 1000 i.u. vitamin A weekly. after correction. 
Wiss, 1958) has been drawn with the same maximum as the difference curve for purposes of comparison. Fig. 2 gives the corresponding curves for heart, but without the curve for pure ubiquinone.

Expt 2. The rats not dosed with vitamin A responded to the deficient diet less regularly than in Expt I, presumably because lard was included. In most of the rats growth stopped after 6 weeks, but three males grew for IO-I I weeks. Eventually all the animals, with one exception, lost weight and developed clear signs of deficiency. The animals dosed with 1000 i.u. of vitamin A weekly remained in good health and had liver reserves averaging $33^{\circ} \mathrm{i} . \mathrm{u} . / \mathrm{g}$. The results are given in Table 2. In the deficient rats the livers contained $330-1100 \mu \mathrm{g} / \mathrm{g}$, mean 6ro, of gross ubiquinone, and the hearts $310-860 \mu \mathrm{g}$, mean 570 . In the dosed rats values for liver were $280-620 \mu \mathrm{g} / \mathrm{g}$, mean 410 , and for heart $37^{\circ}-1100 \mu \mathrm{g}$, mean $53^{\circ}$.

\section{Table 2. Expt 2. Gross amounts of ubiquinone in the livers and hearts of rats deficient in vitamin $A$ or given large doses}

(Corrections for the presence of vitamin $\mathrm{A}$ in liver have been applied)

\begin{tabular}{|c|c|c|c|c|c|c|c|c|c|}
\hline \multirow{4}{*}{$\begin{array}{l}\text { Rat no. } \\
\text { and sex }\end{array}$} & \multirow{4}{*}{$\begin{array}{c}\text { Days } \\
\text { on } \\
\text { diet }\end{array}$} & \multirow{3}{*}{\multicolumn{3}{|c|}{ Body-weight (g) }} & \multirow[b]{4}{*}{ Remarks } & \multicolumn{4}{|c|}{ Ubiquinone } \\
\hline & & & & & & \multicolumn{2}{|c|}{ Liver } & \multicolumn{2}{|c|}{ Heart } \\
\hline & & & & & & & Total & & To \\
\hline & & Initial & Maximal & Final & & $\mu \mathrm{g} / \mathrm{g}$ & $(\mu \mathrm{g})$ & $\mu g / g$ & $(\mu g)$ \\
\hline \multicolumn{10}{|c|}{ Vitamin A-deficient } \\
\hline 170 & $7 \mathbf{r}$ & 49 & 241 & 197 & Xerophthalmia & $55^{\circ}$ & 3800 & 580 & 430 \\
\hline $180^{\pi}$ & 77 & 51 & 289 & 273 & Xerophthalmia & $45^{\circ}$ & 4700 & 490 & 380 \\
\hline 190 & 129 & 55 & 308 & 237 & $\begin{array}{l}\text { Xerophthalmia, septic } \\
\text { prostate }\end{array}$ & 330 & 3800 & 550 & 460 \\
\hline 200 & 129 & 49 & 351 & 266 & Xerophthalmia & 460 & 3600 & 560 & 460 \\
\hline 210 & 137 & 54 & 320 & 312 & Normal & 420 & 5300 & 510 & 500 \\
\hline 229 & 59 & $5^{\circ}$ & I 93 & 150 & Haematuria & 710 & 5200 & 3 Io & 180 \\
\hline 239 & 70 & 45 & 163 & 138 & Died; pyelitis & 690 & 5200 & 860 & 590 \\
\hline $24 ㅇ ㅜ ㄱ$ & 72 & 44 & 173 & 140 & $\begin{array}{l}\text { Xerophthalmia, haema- } \\
\text { turia }\end{array}$ & 730 & 4400 & 570 & 290 \\
\hline $\begin{array}{l}259 \\
269\end{array}$ & $\begin{array}{r}74 \\
108\end{array}$ & $\begin{array}{l}50 \\
47\end{array}$ & $\begin{array}{l}202 \\
203\end{array}$ & $\begin{array}{l}190 \\
160\end{array}$ & $\begin{array}{l}\text { Haematuria } \\
\text { Xerophthalmia, cystitis }\end{array}$ & $\begin{array}{r}620 \\
1100\end{array}$ & $\begin{array}{l}4600 \\
5800\end{array}$ & $\begin{array}{l}590 \\
640\end{array}$ & $\begin{array}{l}380 \\
400\end{array}$ \\
\hline Mea & & 49 & 244 & 206 & & 610 & 4600 & 570 & 410 \\
\hline \multicolumn{10}{|c|}{ Adequately supplied } \\
\hline $27 \sigma$ & 71 & 50 & 329 & 328 & Normal & $35^{\circ}$ & 5400 & 520 & 480 \\
\hline $28 \sigma$ & 77 & 53 & 386 & 386 & Normal & 410 & 4400 & 430 & 420 \\
\hline 298 & 137 & 54 & 467 & 467 & Normal & 380 & 82,00 & 430 & 450 \\
\hline 300 & 140 & 49 & 389 & 389 & Normal & 370 & 5900 & 490 & 510 \\
\hline $31 \delta$ & 140 & 53 & 388 & 388 & Normal & $35^{\circ}$ & 6000 & 500 & 530 \\
\hline 32 & 62 & 50 & 170 & 170 & Normal & 280 & 2300 & 370 & 230 \\
\hline 33 ㅇ & 70 & 45 & 189 & 189 & Normal & 360 & 2900 & 1100 & 640 \\
\hline $34 ㅇ$ & 72 & 45 & 221 & 221 & Normal & 580 & 5200 & 610 & 380 \\
\hline 35 우 & 74 & 49 & 195 & 195 & Normal & 420 & 3800 & 470 & 290 \\
\hline 369 & 108 & 47 & 205 & 203 & Normal & 620 & 5000 & 430 & 270 \\
\hline \multicolumn{2}{|c|}{ Mean } & 49 & 294 & 294 & & 410 & 4900 & 530 & 420 \\
\hline
\end{tabular}




\section{DISCUSSION}

The limitations of our method of estimation have already been emphasized. Two difficulties must be faced in the interpretation of our results. (I) Since the absorption curves observed had never the spectrum of pure ubiquinone, but always showed a less sharp maximum, it is clear that ubiquinone was not the only substance contributing to the absorption at $272-275 \mathrm{~m} \mu$. Our results seem useful as a basis of comparison, however, even if the absolute amounts of ubiquinone are uncertain. (2) Even between rats in the same group the range of variation was usually wide. Comparisons between individual rats were therefore valueless, and statistical methods had to be applied to groups.

Gross ubiquinone in liver. In our first experiment, which did not involve any correction for vitamin A, the mean of $520 \mu \mathrm{g} / \mathrm{g}$ of gross ubiquinone for the livers of deficient rats was about $50 \%$ higher than the mean of $340 \mu \mathrm{g}$ for the livers of normal rats. The difference between the groups was significant $(0.01<P<0.02)$. In our second experiment, in which a substantial correction for vitamin $A$ was necessary, the results for liver were in reasonably good agreement with those of the first experiment. Thus in the deficient rats the mean of $610 \mu \mathrm{g} / \mathrm{g}$ exceeded by about $50 \%$ the mean of $410 \mu \mathrm{g}$ in the normal rats. Again the difference between the groups was significant $(P<0.01)$. The results of both our experiments therefore confirm the finding of Lowe $e$ t al. (1953) and others, that the concentration of ubiquinone is increased in the livers of rats deficient in vitamin $\mathrm{A}$.

In both experiments higher mean concentrations were found in females than in males. The superiority of females over males occurred in both the deficient and the adequately supplied animals. Thus in the first experiment the mean values for females were 610 and $380 \mu \mathrm{g} / \mathrm{g}$ for deficient and adequately dosed respectively as against $44^{\circ}$ and 300 for males. In the second experiment corresponding values were $77^{\circ}$ and $45^{\circ}$ for females and 440 and 370 for males.

Results for the total amounts of gross ubiquinone in the liver, for both sexes together, did not show significant differences between groups $(P>0 \cdot \mathrm{I})$. Thus in the first experiment the mean totals were $3800 \mu \mathrm{g}$ in the normal rats and $3300 \mu \mathrm{g}$ in the deficient rats and in the second experiment 4900 and $4600 \mu \mathrm{g}$ respectively. The reason for the failure of total ubiquinone contents to reflect the differences in concentration lay in the differences between the liver sizes of the deficient and the control rats. For the males in both our experiments the mean weight of the liver was $15.7 \mathrm{~g}$ in normal animals and $8.5 \mathrm{~g}$ in deficient animals. For females the means were $8.3 \mathrm{~g}$ and $6.4 \mathrm{~g}$, respectively. Comparison of the total ubiquinone contents according to sex indicated that vitamin A deficiency caused slightly decreased values in males, and increased values in females.

Pure ubiquinone in liver. These findings for gross ubiquinone suggest that one of the factors causing the high concentration of ubiquinone in the liver of the deficient rat may be a shrinkage in the size of this organ during the period when the body-weight is declining from its maximum. Ubiquinone may be dispersed less rapidly than the liver protein, and may thus be trapped in the tissues.

Inspection of Fig. I (Expt I), however, must raise doubt whether this explanation 
can account completely for the increased concentration of ubiquinone. Thus it will be seen that the mean absorption band at $272 \mathrm{~m} \mu$ was somewhat sharper, as judged by the difference between the maximum at $272 \mathrm{~m} \mu$ and the minimum at $256-260 \mathrm{~m} \mu$, in the deficient rats than in the controls. This difference in sharpness indicates that the proportion of ubiquinone to other substances absorbing at $272 \mathrm{~m} \mu$ was higher in the deficient rats than in the controls. By subtracting the mean absorption curve for the control rats from that for the deficient rats a curve was obtained approaching that of pure ubiquinone in sharpness. At wavelengths close to the maximum at $272 \mathrm{~m} \mu$ the difference in the mean absorption curves between the groups could be adequately explained by the presence of an additional $180 \mu \mathrm{g} / \mathrm{g}$ of pure ubiquinone in the livers of the deficient rats.

As already stated the mean of $340 \mu \mathrm{g} / \mathrm{g}$ liver found for the control group was for gross ubiquinone containing substantial amounts of 'spectroscopic impurities'. It is clear, therefore, that a mean rise of $180 \mu \mathrm{g}$ pure ubiquinone/g liver in the deficient rats represents a higher proportional increase than the $50 \%$ calculated by comparisons of gross ubiquinone contents. Probably the concentration of ubiquinone was about doubled in the deficient rats compared with the controls. An increase of this magnitude in concentration could not be explained completely by differences in the size of the liver between the groups.

Heart. In Expt 1 the mean gross ubiquinone concentrations of $520 \mu \mathrm{g} / \mathrm{g}$ in the deficient rats and $490 \mu \mathrm{g}$ in the controls, with corresponding total amounts of 300 and $360 \mu \mathrm{g}$, were so little different that no statistical examination was required. From Fig. 2 it will be seen that the mean absorption curves were virtually identical. The curve showing the small difference between the groups, in contrast to the same curve for liver (Fig. I), did not show the absorption spectrum of ubiquinone. In Expt 2 the means of 570 and $530 \mu \mathrm{g} / \mathrm{g}$, respectively, with total amounts of 410 and $420 \mu \mathrm{g}$, also suggested that avitaminosis $A$ has no noticeable effect on the ubiquinone contents of the heart. For this experiment we undertook neither statistical examination nor the laborious procedure of working out mean absorption curves.

General comments. According to the experiments of Morton \& Phillips (1959b) the mean concentration of ubiquinone in the livers of rats deprived of vitamin A for $4^{\circ}$ days or longer was about five times higher than in weanling rats that had received the deficient diet for only 5 days. Wide variations were also found, however, between the means for groups of rats classed together as being in similar stages of deprivation. Thus for groups of rats taken at a stage a little below the weight plateau, ubiquinone concentrations of 220,117 and $398 \mu \mathrm{g} / \mathrm{g}$, mean $245 \mu \mathrm{g}$, were found. For groups of rats losing weight as the result of avitaminosis the range was $297-660 \mu \mathrm{g} / \mathrm{g}$, mean $409 \mu \mathrm{g}$. Since the methods at present available for estimating ubiquinone are far from perfect, the validity of the apparent two- or three-fold variations between groups of similar animals, in which the effects of individual variation should at least have been reduced, seems open to question. Moreover, with such a wide range of variation among the results for deficient animals, comparison with the results for normal animals may seem hazardous, particularly in the absence of values for control animals of the same age as the deficient animals. 
Our own findings, therefore, may be helpful in providing further evidence by the statistical comparisons of results for deficient and control rats about the reality of the increase in concentration of ubiquinone in the livers of rats deficient in vitamin A. Apart from the conventional statistical treatment of our results, the comparison of the shape of the mean absorption curves for deficient and control rats gave further and perhaps more conclusive proof of the increase in ubiquinone in avitaminosis $A$. Thus we have seen that the difference between curves for the deficient and control rats could be ascribed solely to increased ubiquinone in the deficient rats. Our results do not seem consistent with so large an increase of ubiquinone as the fivefold one found by Morton \& Phillips (I959b) in the avitaminotic liver. It is clear, however, that the increase is somewhat greater than can be explained by the reduced size of the liver in vitamin A deficiency.

Our results for heart gave no indication of an increased concentration of ubiquinone in parallel with that found in the liver. As to ubichromenol, known to be present in rat's liver in concentrations much lower than those of ubiquinone (Morton \& Phillips, I959 $a, b$ ), our method of spectroscopic examination without the use of chromatography was doubtless too crude for its detection.

Since the increase of ubiquinone in the liver in the vitamin A-deficient rat is not accompanied by a corresponding increase in the heart, it would appear that the biochemical abnormality in ubiquinone metabolism does not equally affect the whole body. Discussion of the specificity of the relationship between the hepatic rise in ubiquinone and avitaminosis A may well await the results of further research.

\section{S U M M ARY}

I. Gross ubiquinone concentrations, in other words the maximum amounts of this substance consistent with the intensity of absorption at $272 \mathrm{~m} \mu$, were measured in the livers and hearts of rats, either deficient in vitamin A or adequately dosed.

2. The tissues were digested with alcoholic potash, in the presence of pyrogallol, and the ubiquinone was extracted, with the rest of the unsaponifiable fraction, for spectroscopic examination without further treatment. When the liver extracts contained more than traces of vitamin A a correction was made to allow for the contribution made by it to the absorption at $272 \mathrm{~m} \mu$.

3. In the liver, in two experiments, the mean concentrations of gross ubiquinone were about $50 \%$ higher in groups of deficient rats than in adequately dosed controls. In each experiment the difference was statistically significant at the $5 \%$ level.

4. The raised ubiquinone concentrations in the livers of the deficient rats were associated with reductions in the sizes of the livers. The total amounts of gross ubiquinone, as opposed to the concentrations, were about the same in deficient and dosed rats.

5. Mean absorption spectra were drawn for liver extracts from a group of rats deficient in vitamin $A$ and from a control group given doses of vitamin $A$ insufficient to allow its storage in the liver. A somewhat sharper maximum at $272 \mathrm{~m} \mu$ was found for the deficient than for the control rats. It indicated that the proportion of ubi- 
quinone to other substances absorbing at $272 \mu \mathrm{g}$ was higher in the deficient than in the control rats. On subtraction of the absorption curve for the control rats from that for the deficient rats, an absorption spectrum approaching that of pure ubiquinone was obtained.

6. The increase in the concentration of pure ubiquinone in the livers of deficient rats must therefore be somewhat greater than the $50 \%$ deduced from comparing gross ubiquinone contents in deficient and control rats.

7. In the heart no differences in ubiquinone concentrations were found between deficient and control rats.

8. These results confirm that the concentration of ubiquinone is increased in the livers of rats deficient in vitamin A. The increase can be explained partly, but not entirely, by the reduced size of the liver. The results for heart indicate that ubiquinone does not increase uniformly throughout the body in avitaminosis A. The specificity of the relationship between avitaminosis $A$ and increased hepatic ubiquinone remains open to question.

Our thanks are tendered to Dr L. J. Harris for his valuable criticism and to Miss M. A. Smith for skilful technical assistance.

\section{REFERENCES}

Ames, S. R. \& Harris, P. L. (1954). Science, 120, 391.

Cama, H. R., Collins, F. D. \& Morton, R. A. (195I). Biochem. F. 50, 48.

Cunningham, N. F., Lowe, J. S., Mervyn, L., Morton, R. A. \& Vernon, J. (1955). Biochem. F. 60, xviii.

Fahmy, N. I., Hemming, F. W., Morton, R. A., Paterson, J. Y. F. \& Pennock, J. F. (1958). Biochem. F. 70, I $P$.

Hatef, Y., Lester, R. \& Ramasarma, T. (1958). Fed. Proc. r7, 238.

Heaton, F. W., Lowe, J. S. \& Morton, R. A. (1955). Biochem. F. 60, xviii.

Heaton, F. W., Lowe, J. S. \& Morton, R. A. (1957). Biochem. F. 67, 208.

Laidman, D. L., Morton, R. A., Paterson, J. Y. F. \& Pennock, J. F. (1959). Chem. E Ind. p. ror9.

Lester, R. L., Crane, F. L. \& Hatef, Y. (1958). F. Amer. chem. Soc. 80, 4751.

Lester, R. L., Hatefi, Y., Widmer, C. \& Crane, F. L. (1959). Biochim. biophys. Acta, 33, 169.

Lowe, J. S., Morton, R. A. \& Harrison, R. G. (1953). Nature, Lond., r72, 716.

Martin, A. J. P., Moore, T., Schmidt, M. \& Bowden, F. P. (1934). Nature, Lond., 134, 214.

Moore, T. \& Rajagopal, K. R. (I 940). Biochem. F. 34, 335.

Moore, T. \& Sharman, I. M. (1959). Biochem. F. 73, 6 P.

Morton, R. A. (1958). Nature, Lond., 182, I764.

Morton, R. A., Gloor, U., Schindler, O., Wilson, G. M., Chopard-dit-Jean, L. H., Hemming, F. W., Isler, O., Leat, W. M. F., Pennock, J. F., Rüegg, R., Schwieter, U. \& Wiss, O. (1958). Helv. chim. acta, 41, 2343.

Morton, R. A. \& Heilbron, I. M. (1928). Nature, Lond., 122, 10.

Morton, R. A. \& Phillips, W. E. J. (1959a). Biochem. F. 73, 32 P.

Morton, R. A. \& Phillips, W. E. J. (1959b). Biochem. 7. 73, 419.

Tosic, J. \& Moore, T. (1945). Biochem. F. 39, 498.

Ward, R. J. \& Moore, T. (1955). Biochem. F. 59, xv. 